\title{
Espectrometría de difracción por rayos laser
}

\section{Difraction spectrometry by laser beams}

\begin{abstract}
RESUMEN
Los avances en la tecnología laser han permitido el desarrollo de múltiples aplicaciones, en concreto la espectrometria de difracción de rayos laser para la determinación de la curva de distribución del tamaño de particula de diferentes materiales, y que permite la obtención de la misma tanto en seco como en húmedo. En este trabajo se hace una descripción breve de la técnica y de sus fundamentos. Se presentan resultados con diferentes materiales: caliza, arcilla, yeso, cemento portland y materiales siliceos.
\end{abstract}

\author{
M. FRIAS, M. P. DE LUXAN Y M. I. SANCHEZ DE ROJAS
}

IETcC/CSIC

Serrano Galvache, s/n. 28033 Madrid/España

\section{INTRODUCCION}

Desde hace ya años, el conocimiento del tamaño de las partículas que constituyen un material es una de las características físicas a la que se ha venido prestando atención prioritaria, debido a su relación directa con sus propiedades, lo que condicionará su posterior utilización para un empleo especifico. Por esta razón, tanto los laboratorios de investigación como los sectores industriales, han trabajado en este campo. En un principio, se comenzó por el desarrollo de métodos de ensayo y de las técnicas instrumentales adecuadas que permitían conocer la granulometría de una muestra y, más tarde, se establecieron correlaciones entre su finura y su comportamiento, y así llegar a seleccionar, como es el caso de la industria del cemento, una distribución granulométrica óptima para una determinada aplicación, ya que como es sabido, existe una relación estrecha entre la finura y la reactividad del material que condicionan las propiedades físicas y mecánicas del cemento (1).

Los trabajos pioneros sobre la medida de la finura se deben a R. L. Blaine (2) y a L. A. Wagner (3), quienes desarrollaron métodos para la determinación de la SUPERFICIE ESPECIFICA.

\section{SUMMARY}

The advances in laser tecnology have permitted the development of numerous applications, in particular diffraction spectrometry by laser beams for the determination of the distribution curve of the particle sizes of different materials; this permits one to obtain the distribution of particle size in both wet and dry materials. In the present paper a brief description of the technique and its principles is offered. The results obtained with different materials-limestone, clay, gypsum, portland cement and siliceous materials are given. 
La dificultad de conocer las características de los materiales, especialmente en lo que se refiere a làs partículas que lo constituyen, su tamaño, distribución, morfología, etc., ... hizo que, desde sus inicios, se hayan diseñado numerosos métodos y las consiguientes técnicas instrumentales, pero que en cuyo punto de partida se fijan un conjunto de hipótesis acerca de las partículas, que hacen que se alejen los resultados obtenidos de las características propias del material. Sin embargo, es posible verificar la relación entre ios valores hallados en los análisis granulométricos y las propiedades de los materiales.

Así, fueron apareciendo nuevas técnicas, algunas de ellas ya clásicas, entre las que se pueden citar: la pipeta de ANDREASEN (4), (5); la BALANZA DE SEDIMENTACION; el tamizador-neumático ALPINE; el elutriadorcentrifugador BAHCO; el SEDIGRAPH (6), (7); el método del HIDROMETRO (8). Todas ellas tienen gran importancia pero, sin embargo, los resultados se obtienen con mucha lentitud.

EL COULTER-COUNTER es más rápido que las técnicas mencionadas anteriormente en cuanto se refiere al análisis de un determinado rango de tamaño de partícula; sin embargo se necesita tiempo para la preparación de la muestra debido a la necesidad de obtener las fracciones correspondientes para sus determinaciones posteriores. (9), (10).

Los METODOS OPTICOS se han utilizado en forma creciente desde hace años para la medida de las distribuciones de los tamaños de partícula. Y, en la actualidad, es la TECNOLOGIA LASER la que ha alcanzado su gran protagonismo, ya que es capaz de proporcionar resultados con rapidez, precisión y reproducibilidad, por lo que en el momento presente se sitúa como un método alternativo a los ya existentes y anteriormente mencionados (11).

\section{ESPECTROMETRIA DE DIFRACCION POR RAYOS LASER}

\subsection{Fundamento}

El principio físico de un analizador de difracción, es bien conocido desde hace muchos años. J. Fraunhofer en 1817 (12) describió un sistema de producir figuras de difracción cuya diferencia con los métodos actuales empleados, se basa sólo en el foco luminoso, (Figura 1).

Al hacer pasar un rayo laser monocromático expandido a través de una muestra
The difficulties involved in establishing the characteristics of certain materials, specially regarding those of their constituent particles and their size, distribution, morphology etc,..., has resulted in the design of many methods for such purposes and their consequent instrumental techinques; in these a set of hypotheses concerning the particles is initially laid down that makes the results obtained diverge from the actual characteristics of the material. However, it is possible to verify the relationship between the values found in the granulometric analysis and the properties of the material.

Accordingly, new techniques were proposed, some of them by now classic, among which the following could be cited: the ANDREASEN pipette (4), (5); the SEDIMENTATION BALANCE; the ALPINE pneumatic-siever; the BAHCO elutriator-centrifuge; the SEDIGRAPH (6), (7); the HYDROMETER method (8). All of them are of great importance but the results can only be obtained very slowly.

The COULTER COUNTER is faster than the above-mentioned techniques regarding the analysis of a given range of particle size; however, time is required for preparation of the samples due to the need to obtain the corresponding fractions for their later determination, (9), (10).

For several years OPTIC METHODS have been used with increasing frequency for the measurement of the distributions of particle sizes. Currently LASER TECHNOLOGY has become the most popular since it is able to afford results with great speed, precision and reproducibility and is therefore an alternative method to existing ones and those mentioned above (11).

\section{DIFFRACTION SPECTROMETRY BY LASER BEAMS}

\subsection{Principle}

The physical principles of diffraction analyzers have been known for many years. In $1817 \mathrm{~J}$. Fraunhofer (12) described a system for producing diffraction images that only differed from current methods in its light source (Figure 1).

On passing an expanded monochromatic laser beam through a pulverized sample, either dry 
pulverizada, en seco o en suspensión en un líquido no reactivo, la luz se difracta y se produce una figura de difracción de simetría radial en el plano focal de la lente. Si todas las partículas iluminadas son de tamaño único, el rayo laser formará una figura de difracción, cuya energía de distribución sigue la Ley de AIRY (13).

La intensidad luminosa de los anillos claros es directamente proporcional al número de partículas vistas con el haz luminoso, y los radios de los anillos son inversamente proporcionales al diámetro de las partículas.

Cuando las partículas tienen tamaños diferentes, la figura de difracción obtenida se basa en una superposición de imágenes de AIRY, (Figuras 2 y 3 ) cada una de las cuales corresponde a un diámetro diferente de partícula.

Y cuya intensidad disminuye con la distancia al centro. A partir de esta figura de difracción or in a non-reactive liquid, the light is diffracted and a diffraction image with radial symmetry is produced on the focal plane of the lens. If all the particles illuminated are of the same size, the laser beam will form a diffraction image whose distribution energy follows the Law of AIRY (13).

The intensity of the light rings is directly proportional to the number of particles seen with the beam of light and the radius of the rings are inversely proportional to the diameter of the particles.

When the particles are of different sizes, the diffraction image obtained is based on a superimposition of AIRI images (Figures 2 and 3), each of which corresponds to a different particle size and whose intensity decreases with the distance from the centre. From this diffraction image it is possible to obtain the granulometric distribution of a sample by a

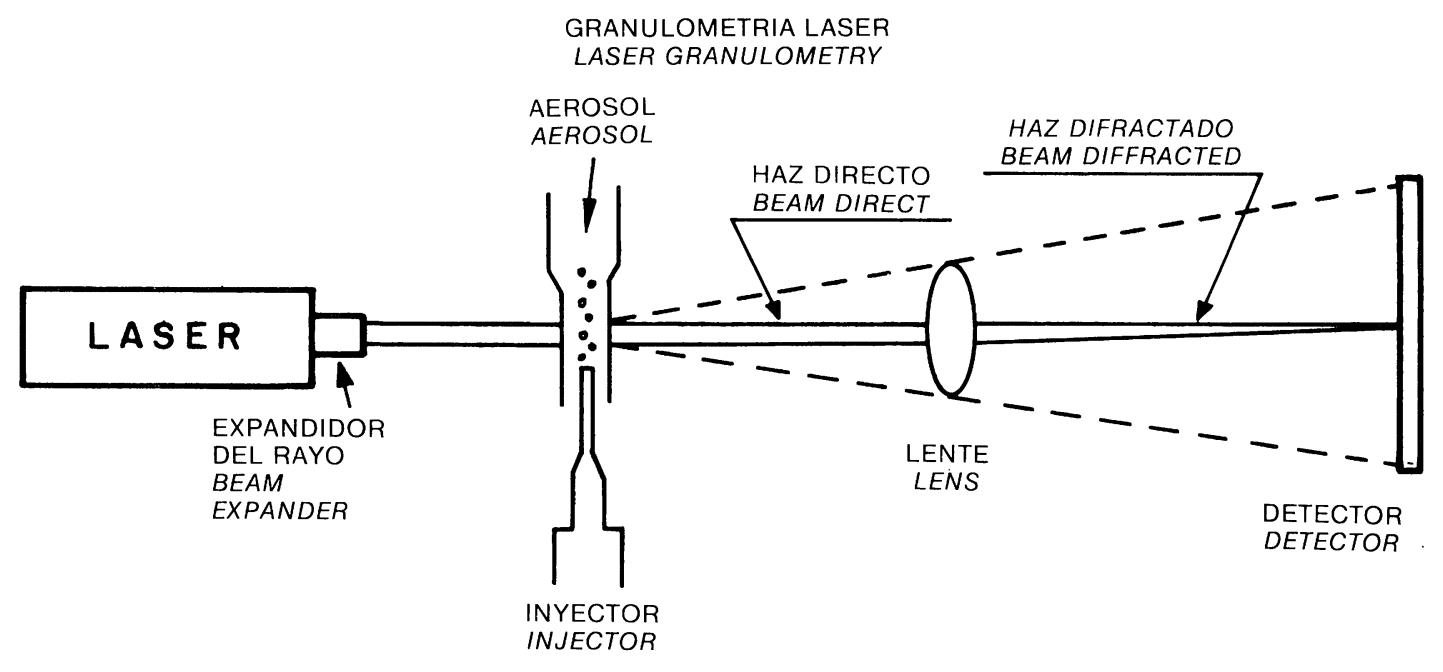

Fig. 1.-Esquema general. Fig. 1.-General scheme.

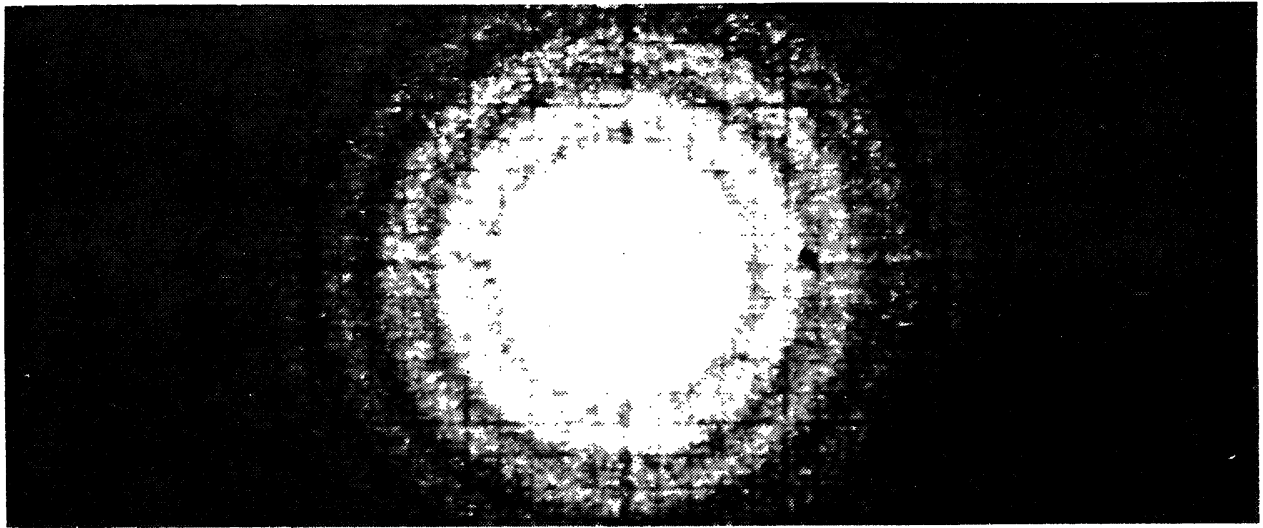

Fig. 2.-Anillos airy.

Fig. 2.-Airy rings. 


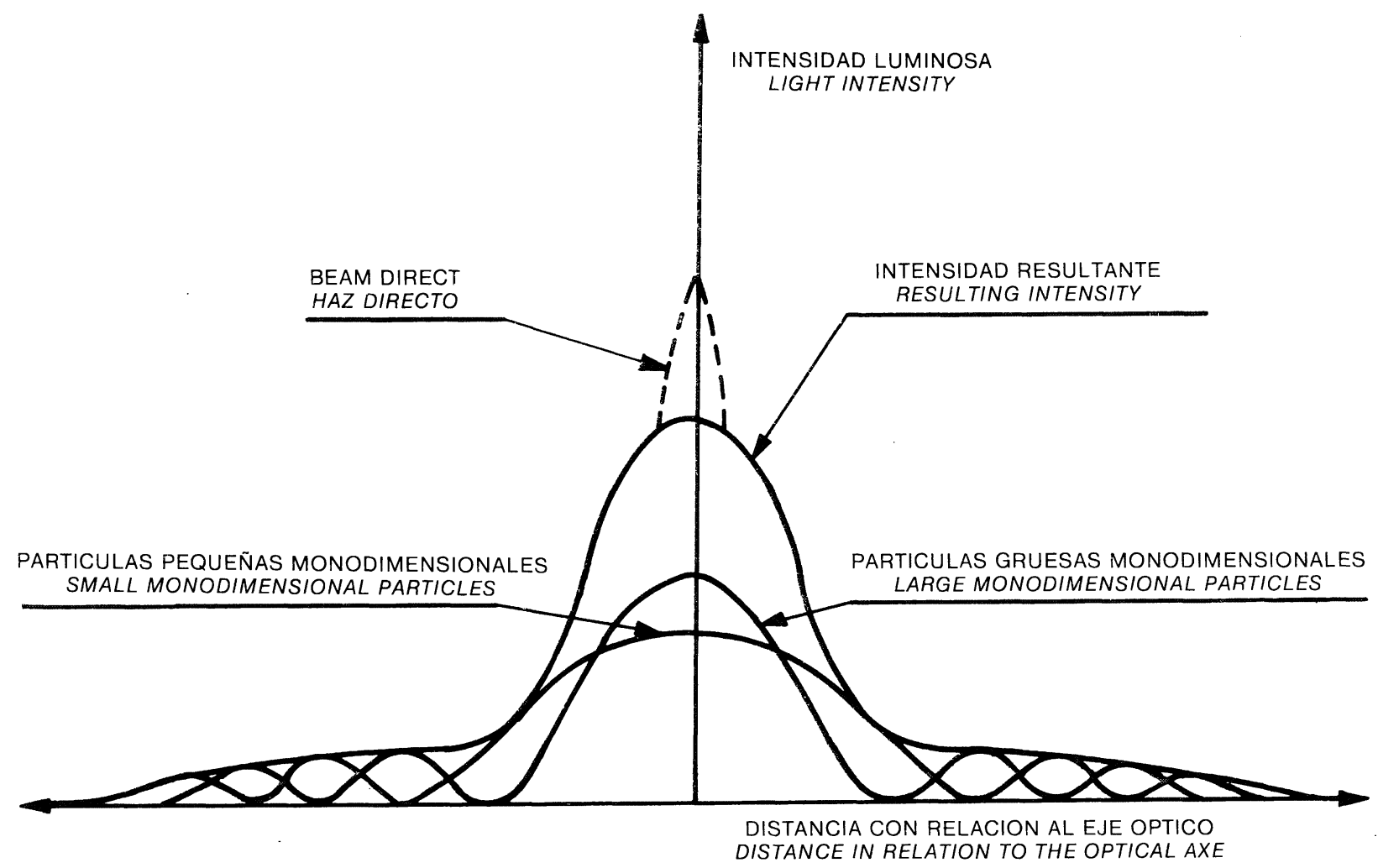

Fig. 3.-Curvas de distribucion de intensidad luminosa difractada.

Fig. 3.-Distribution curves of diffracted light intensity.

se obtiene la distribución granulométrica de una muestra, mediante una serie de tratamientos y aproximaciones matemáticas.

\subsection{Descripción del equipo}

El equipo adquirido en el Instituto Eduardo Torroja de la Construcción y del Cemento, es un espectrómetro de difracción por rayos láser tipo Sympatec Helos 12 KA. (Figura 4). series of treatments and mathematical approximations.

\subsection{Description of apparatus}

The equipment purchased by the "Instituto Eduardo Torroja de la Construcción y el Cemento" is a laser beam diffraction spectrometer (Sympatec Helos 12 KA). (Figure 4).

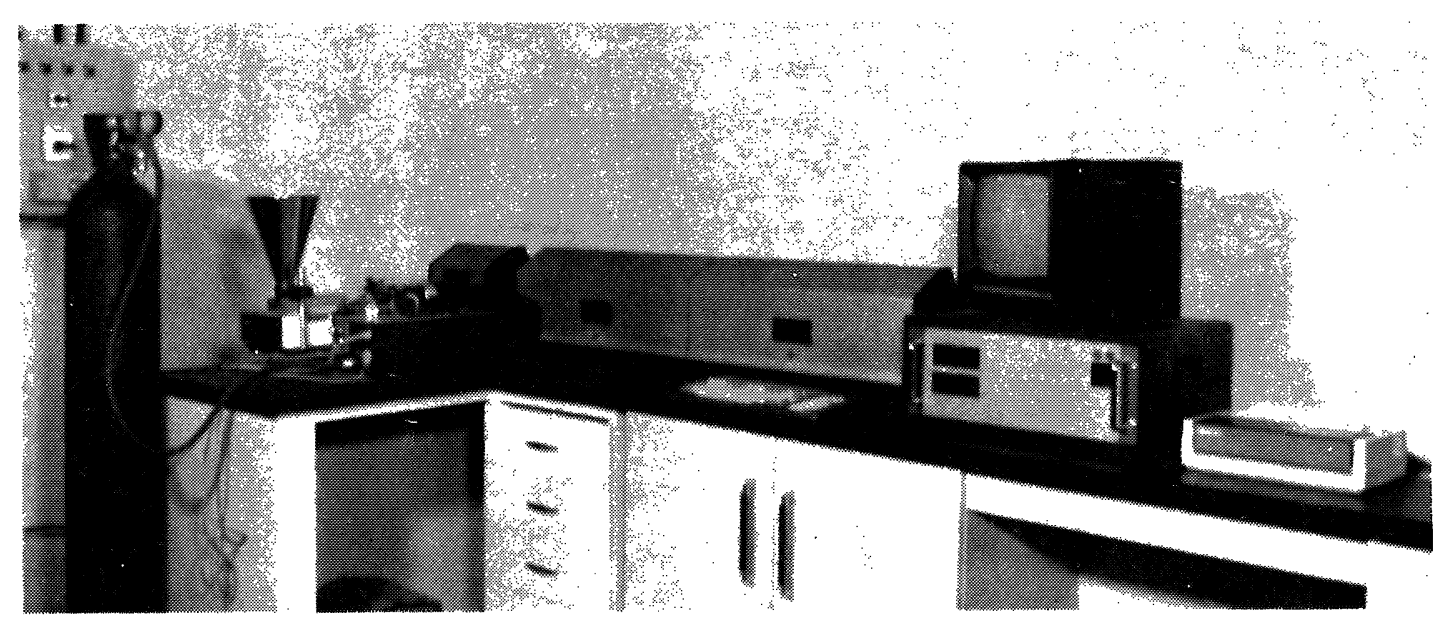

Fig. 4.-Granulómetro laser.

Fig. 4.-Laser granulometer. 
Comprende: dos fuentes de alimentación alternativas: seco, suspensión; sistema óptico; sistema para el proceso de datos; y una impresora modelo HP Think-Jet. Las características del equipo se describen a continuación:

\section{SISTEMA DE ALIMENTACION Y DISPERSION}

A) Sistema Rodos (Figura 5)
It comprises the following elements; two alternative power sources: for dry materials and for suspensions; an optical system; a system for data processing and an HP ThinkJet plotter. The characteristics of the apparatus are as follows:

\section{POWER AND DISPERSION SYSTEM}

A) Rodos System (Figure 5)

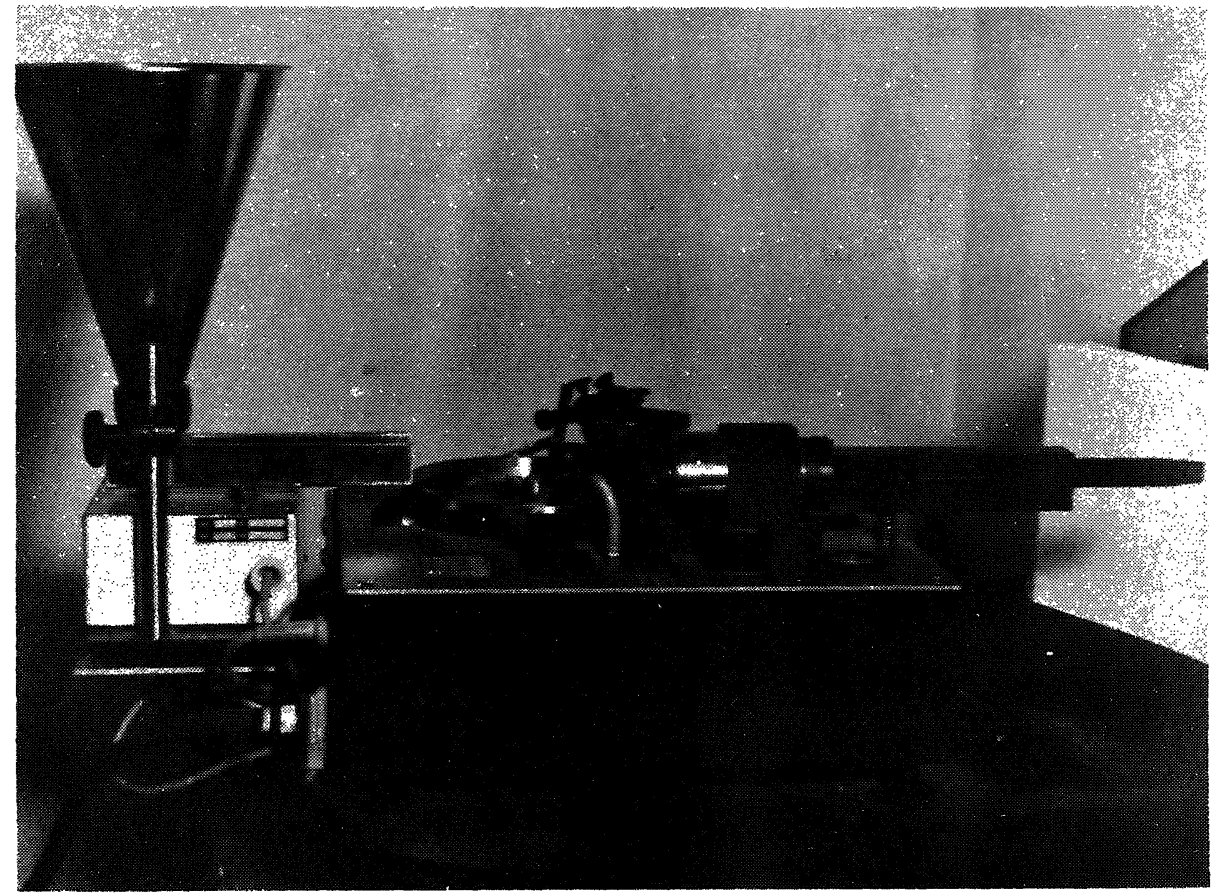

Fig. 5.-Sistema de alimentación y dispersión en fase seca.

Fig. 5.-Power system and dispersion in the dry phase.

Se emplea como generador de aerosoles (gas, sólidos) para análisis de tamaño de partícula en fase seca.

Los elementos principales que componen este sistema son:

- Depósitos con rampa vibrante.

- Rueda de alimentación, de velocidad variable.

- Rodillo de compactación.

- Inyector de Venturi regulable.

- Sistema de dispersión en seco.

- Aspirador de recogida de polvos.

Mediante este mecanismo se consigue una alimentación y dispersión de forma continua de sólidos finamente divididos en estado
The Rodos system is used for the generation of aerosols (gas, solids) for analysis of particle size in the dry phase.

The main elements comprising this system are as follows:

- Reservoir with feed vibrator.

- Rotary table with variable speed.

- Compactation roller.

- Regulable Venturi injector.

- System for dry dispersion.

- Aspirator for collecting the powder.

With this device it is possible to achieve a continuous power source and dispersion of particles divided finely in the dry phase, an 
seco, requisito fundamental para superar las fuerzas de atracción entre las partículas (14), (15). essential requisite for overcoming the forces of attraction between the particles (14, (15).

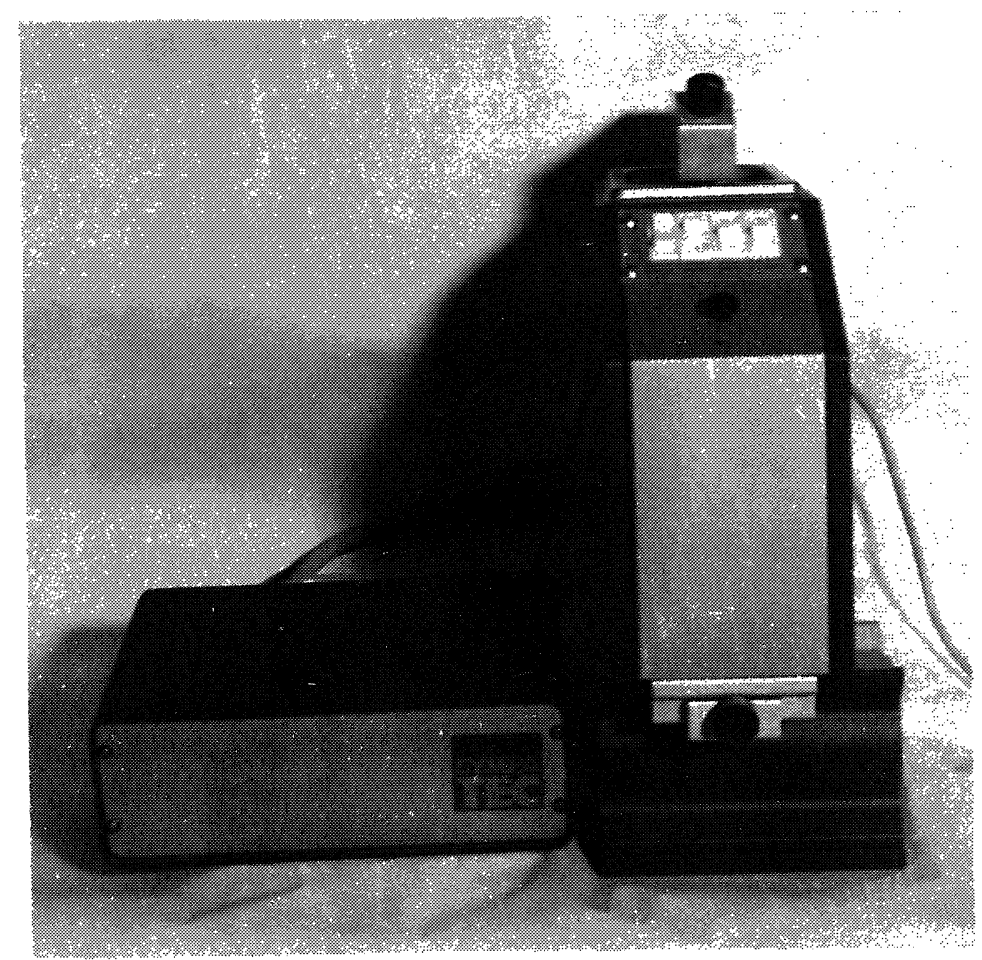

Fig. 6.-Sistema de alimentación y dispersión en fase liquida.

\section{B) Sistema en suspensión (Figura 6)}

Permite la determinación granulométrica de una muestra en medio líquido no reactivo. Es un método alternativo de la fase seca. Tiene la ventaja principal de que al utilizar un equipo de ultrasonidos, se eliminan las fuerzas electrostáticas y de Van der Wals, problema típico cuando se trabaja en fase seca.

\section{Está compuesto por:}

- Recipiente de $300 \mathrm{~mL}$ de capacidad.

- Agitadores con regulación electrónica.

- Ultrasonidos.

- Bomba peristáltica.

\section{SISTEMA OPTICO}

Tiene la finalidad de recoger en el detector las energías difractadas, cuando se le hace pasar un rayo laser a través de una muestra dispersa. De este modo se consigue obtener el análisis granulométrico de partículas.
Fig. 6.-Power system and dispersion in the liquid phase.

This allows the granulometric determination of a sample in a non-reactive liquid medium. It constitutes an alternative to the dry phase method. The main advantage of this method is that on using an ultrasonic it is possible to eliminate the electrostatic and Van der Waals forces, which are typical disadvantages when using the dry phase technique.

The equipment comprises the following elements:

- A $300 \mathrm{~mL}$ capacity vessel.

- Shakers with electronic regulation.

- An ultrasonic.

- A peristaltic pump.

\section{OPTICAL SYSTEM}

The aim of this system is to record on the detector the diffracted energies when a laser beam is passed through a dispersed sample.

It is then possible to obtain a granulometric analysis of the particles. 
Se compone de:

- Un banco óptico, incluyendo los componentes necesarios para la difracción de figuras, tales como:

- Lámpara láser $\mathrm{He} / \mathrm{Ne}$ de $5 \mathrm{~mW}$.

- 4 distancias focales con su rango de medida, (Tabla I).
The system comprises the following:

- An optical unit that includes the components necessary for the diffraction of energies, such as:

- A $5 \mathrm{~mW} \mathrm{He/Ne} \mathrm{laser} \mathrm{source.}$

- Four focal distances with their measurement range (Table I).

TABLA I (TABLE I)

Posibilidades en el rango de la medida

Posibilities in the measurement range

\begin{tabular}{|c|c|}
\hline $\begin{array}{c}\text { Distancias focales }(\mathrm{mm}) \\
\text { [Focal distances }(\mathrm{mm})]\end{array}$ & $\begin{array}{c}\text { Rango de medida }(\mu \mathrm{m}) \\
\text { [Measurement range }(\mu \mathrm{m})]\end{array}$ \\
\hline 100 & $0,75-175$ \\
200 & $1,50-350$ \\
500 & $3,75-875$ \\
1.000 & $7,50-1.750$ \\
\hline
\end{tabular}

- Detector multicelular con 31 canales de medición.

- Y, sistema de lentes y espejos.

- Autofoco: permite el ajuste automático y manual del detector multicelular con respecto a la dirección del rayo laser.

Por último, el equipo está dotado de un:

\section{SISTEMA DE TRATAMIENTO DE DATOS}

Realiza la recogida y posterior tratamiento de los datos. El sofware del sistema de datos puede operar en tres formas diferentes:

1) Sistema operativo (UCSD P-System): Permite la utilización de diferentes opciones previas al análisis: formateo, directorios, grabados, cambios de nombres de archivos, etc.

2) Sistema de medidas "Helos": Hace posible el cálculo del análisis granulométrico. Presenta tres comandos de ejecución:

a) Información: Como su nombre indica, proporciona toda la información necesaria para la introducción de los parámetros en el Menú principal.
- A mutlticell detector with 31 measuring channels.

- And, a system of lenses and mirrors.

- Autofocus: this permits automatic and manual adjustment of the multicell device with respect to the direction of the laser beam.

Finally, the equipment is endowed with:

\section{DATA TREATMENT SYSTEM}

The purpose of this is to collect and then treat the data. The software of the data system is able to operate in three different ways:

1) Operative system (UCSD-P system): This permits the use of different options before analysis: formatting, directories, recording of data, changes in file names, etc.

2) "Helos" measurement system: This makes it possible to calculate the granulometric analysis. It has three execution commands:

a) Information: As indicated in the name, this element provides all the necessary information for introducing the parameters in the main Menu. 
b) Medida: Presenta diferentes opciones para realizar los análisis granulométricos, tanto en medio seco como en suspensión, dependiendo de la cantidad y naturaleza de las muestras.

c) Proceso: Permite, tanto el cálculo de distribución de tamaño de partícula realizado anteriormente, con su correspondiente acumulación de curvas en la misma gráfica (máximo 25), como el control automático de algunas funciones.

3) Sistema de cálculos "QX": Permite el tratamiento posterior de los análisis según la información que se quiere obtener.

Tiene varias opciones:

a) QX-Base: Permite el cálculo de distribución de diferentes formas y la posibilidad de introducir resultados obtenidos por otros equipos y su comparación posterior.

b) QX-Graph: Hace posible el cálculo de la superficie específica, curvas de separación (TROMP), representaciones gráficas de diferentes tipos, etc.

c) QX-Plus: Presenta varias posibilidades como en las curvas anteriormente referidas, principalmente cálculos de valores intermedios, sobre todo procesos de simulación y separación de mezclas.

d) Impresión de datos: Accede a la posibilidad de representar, tanto en pantalla como por impresora, los análisis y tratamientos posteriores en diferentes formatos, dependiendo de las coordenadas elegidas.

3. APLICACIONES DE LA ESPECTROMETRIA DE DIFRACCION POR RAYOS LASER AL ANALISIS GRANULOMETRICO DE MATERIALES EN EL CAMPO DEL CEMENTO

Los primeros trabajos de investigación sobre la espectrometría de difracción por rayos laser se llevaron a cabo a comienzos de los años 70 por M. R. Peltier (16), (17), y fueron desarrollados en el Centre d'Etudes et Recherches de l'Industrie des Liants Hydrauliques (CERILH, Paris). A partir de este momento, la técnica se difunde por b) Measurement: This offers different options for performing the granulometric analyses, both in dry media and suspensions, according to the amount and nature of the samples.

c) Processing: This permits both calculation of the distribution of particle size carried out previously with the corresponding accumulation of curves on the same plot, (maximum 25) and automatic control of certain functions.

3) The "QX" calculation system: This permits later treatment of the analyses according to the information one wishes. to obtain.

It has several different options:

a) QX-Base: This permits the calculation of the different shapes and the possibility of introducing the results obtained by other apparatus and comparison with them.

b) QX-Graph: This make it possible to calculate the specific surface area, separation curves (TROMP), graphic plots of different kinds, etc.

c) QX-Plus: This has various possibilities as in the above -mentioned curvesmainly the calculation of intermediate values and above all permits processes of simulation and separation of mixtures.

d) Data printing: This allows one to represent, both on the monitor screen and on the graphic plotter, the analyses and data treatments in different formats, according to the coordinates chosen.

\section{3) APPLICATIONS OF SPECTROMETRY BY LASER BEAMS TO THE GRANULOMETRIC ANALYSIS OF MATERIALS IN THE CEMENT INDUSTRY}

The first research work carried out in the field of diffraction spectrometry by laser beams was carried out towards the end of the seventies by M. R. Peltier (16), (17) and were developed at the Centre D'etudes et de Recherches de L'Industrie des Liants Hydrauliques (CERILH, Paris). Thereafter, the technique was passed on to reasearch laboratories specializing in the 
los laboratorios de investigación de la especialidad y aparecen numerosas publicaciones que exponen, bien fundamentos teóricos, bien aplicaciones a los cementos (18), (19), (20), (21), (22).

El punto de partida del análisis granulométrico es la suspensión de la muestra en polvo. Para ello, los primeros equipos disponian de un sistema exclusivo de fase líquida.

En el apartado anterior se realizaba la descripción del equipo disponible, mencionando los dos sistemas de alimentación: suspensión en fase líquida (alcohólica, acuosa, ...) y en fase gaseosa (sistema RODOS).

A continuación se presentan distintos análisis granulométricos de varios materiales relacionados con el sector del cemento, cuya obtención se ha realizado en diferentes condiciones. Se han elegido, para su exposición: cemento portland, arcilla, yeso, caliza y roca opalina.

\subsection{Distribución de los tamaños de partículas}

\section{A) Cemento portland}

El análisis granulimétrico de un cemento portland comercial se ha realizado mediante suspensión de la muestra en fase gaseosa y en fase líquida, para poder comparar los resultados.

Para conocer el significado de las expresiones que aparecen en las tablas donde se exponen los valores obtenidos, se presenta la Tabla II. field and many publications appeared that dealt either with theoretical aspects or practical applications to the cement industry (18), (19), (20), (21), (22).

The starting point for granulometric analysis is suspension of the sample in power form. To achieve this, early workers used a system involving exclusively alliquit phase.

In the previous section a description of the available equipment was offered, mentioning the two power sources: suspension in a liquid phase (alcohol, water) and gas phase (RODOS system).

Let us mow examine different granulometric analyses of several materials related with the cement industry; these are obtained by different procedures. As examples the following have been chosen: portland cement, clay, gypsum, limestone and opaline rock.

\subsection{Distribution of particle size}

\section{A) Portland cement}

Granulometric analysis of a commercial Portland cement was carried out in the gas and liquid phases in order to compare the results.

Table II is offered in order to discover the meaning of the expressions appearing in the Tables showing the values obtained. The

TABLA II (TABLE II)

Significado de las expresiones que aparecen en el listado de las Tablas III y $\mathrm{V}$ Meaning of expressions appearing in the listing of Tables III and $\mathrm{V}$

\begin{tabular}{|c|c|}
\hline $\begin{array}{l}\text { xo/mym } \\
\text { Q3/\% }\end{array}$ & $\begin{array}{l}\text { Tamaño de diámetro de partícula, en } \mu \mathrm{m} \text { (Particle diameter, in } \mu \mathrm{m}) \text {. } \\
\text { Curva de distribución acumulada ( } \% \text { de producto por debajo del diámetro de partícula correspon- } \\
\text { diente), (xo/mym). [Cumulative distribution curve (\% of product below corresponding particle size), } \\
(x \circ / m y m)] .\end{array}$ \\
\hline $\mathrm{xm} / \mathrm{mym}$ & Valor medio del diámetro de partícula. (Mean value of particle diameter). \\
\hline $\mathrm{q} 3 / 1 / \mathrm{mm}$ & Densidad de distribución numérica. (Numerical density distribution). \\
\hline q3* & Distribución diferencial. (Differential distribution). \\
\hline $\mathrm{dQ3/ \%}$ & Porcentaje de producto para cada tamaño de partícula. (Percentage of product for each particle size) \\
\hline$M-1,3$ & Momento relacionado con la superficie especifica. (Moment related to specific surface area). \\
\hline Optical concent. & Concentración durante el análisis. (Concentration during analysis). \\
\hline
\end{tabular}


La distribución de los tamaños de partícula de la muestra de cemento, mediante suspensión en fase húmeda, se recogen en las Tablas III y IV y en los histogramas respectivos, (Figuras 7 y 8). distribution of particle size of the sample of cement, by suspension in the liquid phase, is shown in Table III and IV and in the respective histograms (Figures 7 and 8).

TABLA III (TABLE III)

Distribución del tamaño de partícula de un cemento portland Distribution of particle size of a portland cement

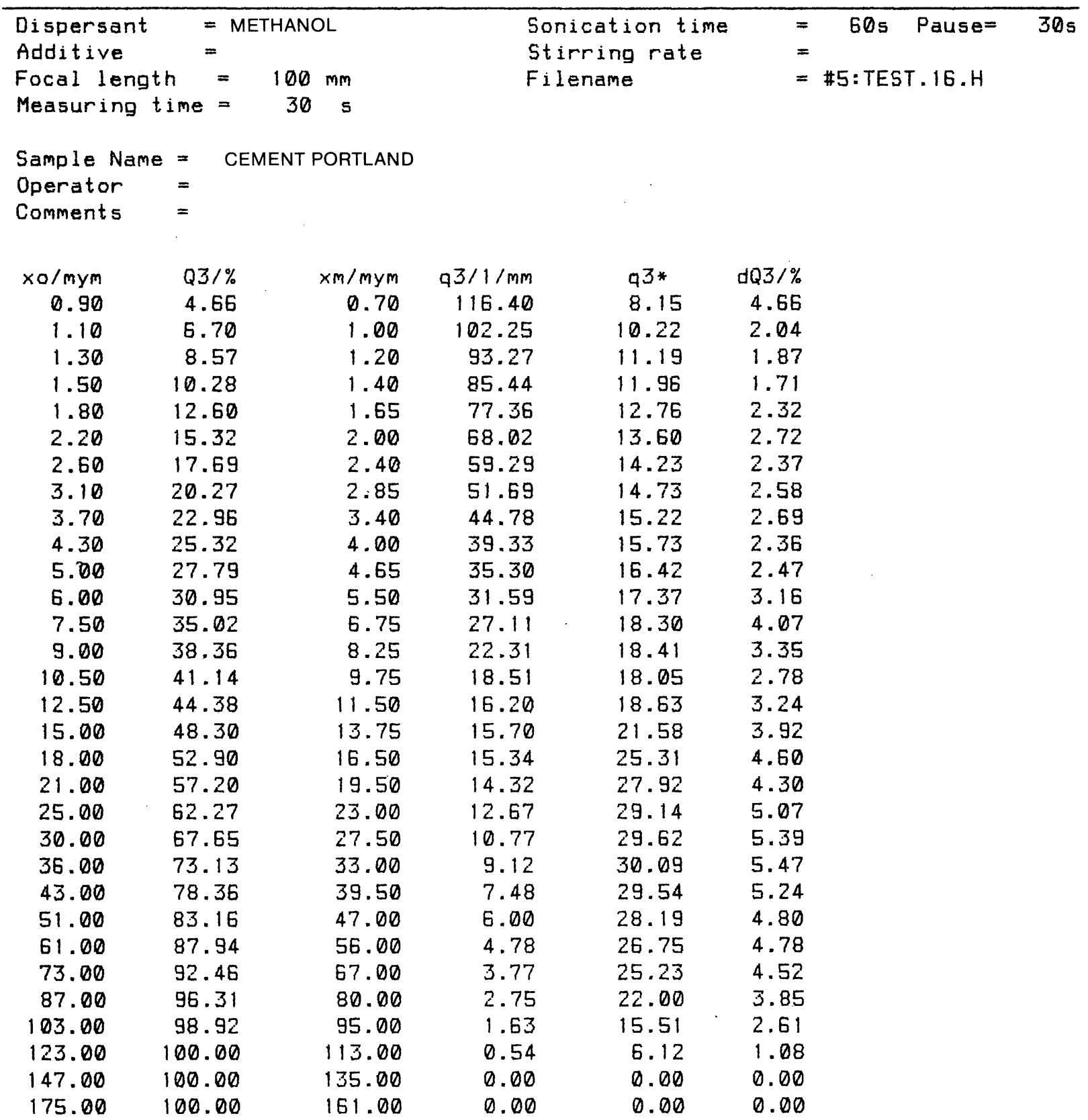

Tamaños de partículas para diferentes porcentajes fijados de muestra.

Particle sizes for different fixed percentages of samples.

$\times 10=1.47$ mym $\times 50=16.08 \mathrm{mym} \times 90=66.11 \mathrm{mym}$
$\times 2.5=0.63 \mathrm{mym} \times 25=4.22 \mathrm{mym} \times 75=38.36 \mathrm{mym}$
$M-1,3=2.20331 \mathrm{E}-1 \mathrm{~m} * 2 / \mathrm{cm} * 3$ optical concent. $=15.8 \%$


La figura 7 representa el residuo inferior a un tamaño de partícula. En ella se han representado conjuntamente las curvas granulométricas de la muestra de cemento en suspensión con fase líquida y en suspensión con fase gaseosa, cuyo listado se reproduce en la Tabla V.
Figure 7 represents the residue lower than a particle size. In the figure, we have represented the granulometric curves of the cement sample in suspension in the liquid phase and in the gas phase whose computer listing is shown in Table $V$.

TABLA IV (TABLE IV)

Distribución del tamaño de partícula (Tabla III) expresada como intervalo Distribution of particle size (Table III) expressed as range

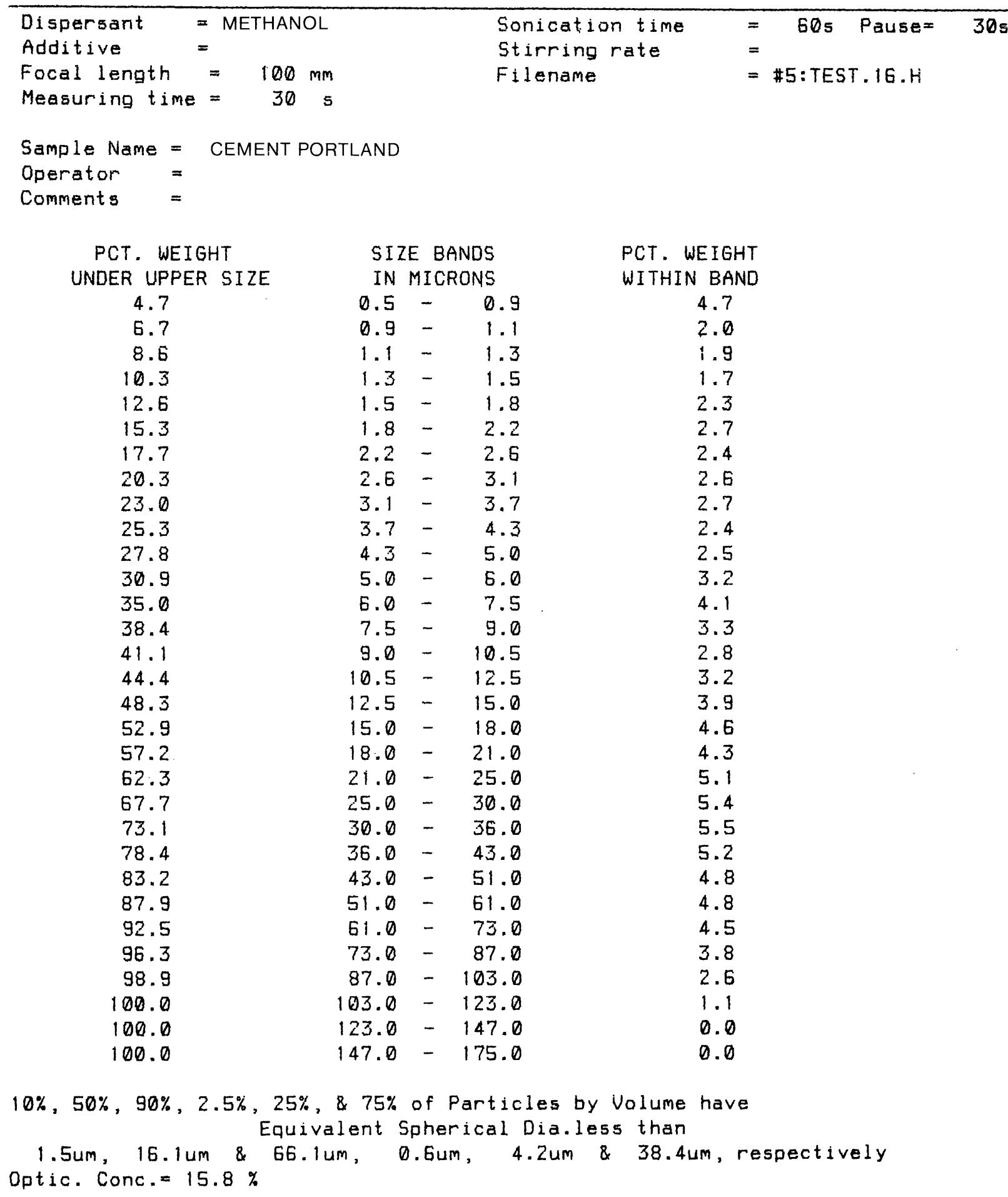


En las cabeceras de las Tablas III y V figuran las condiciones de ensayo respectivas.

Las variaciones en la granulometría obtenida producidas por la utilización de un sistema
The heading of Tables III and V show the respective test conditions.

The variations in the granulometry obtained from the use of a different power source for

TABLA $V \quad$ (TABLE V)

Distribución del tamaño de partícula de un cemento portland Distribution of particle size of a portland cement

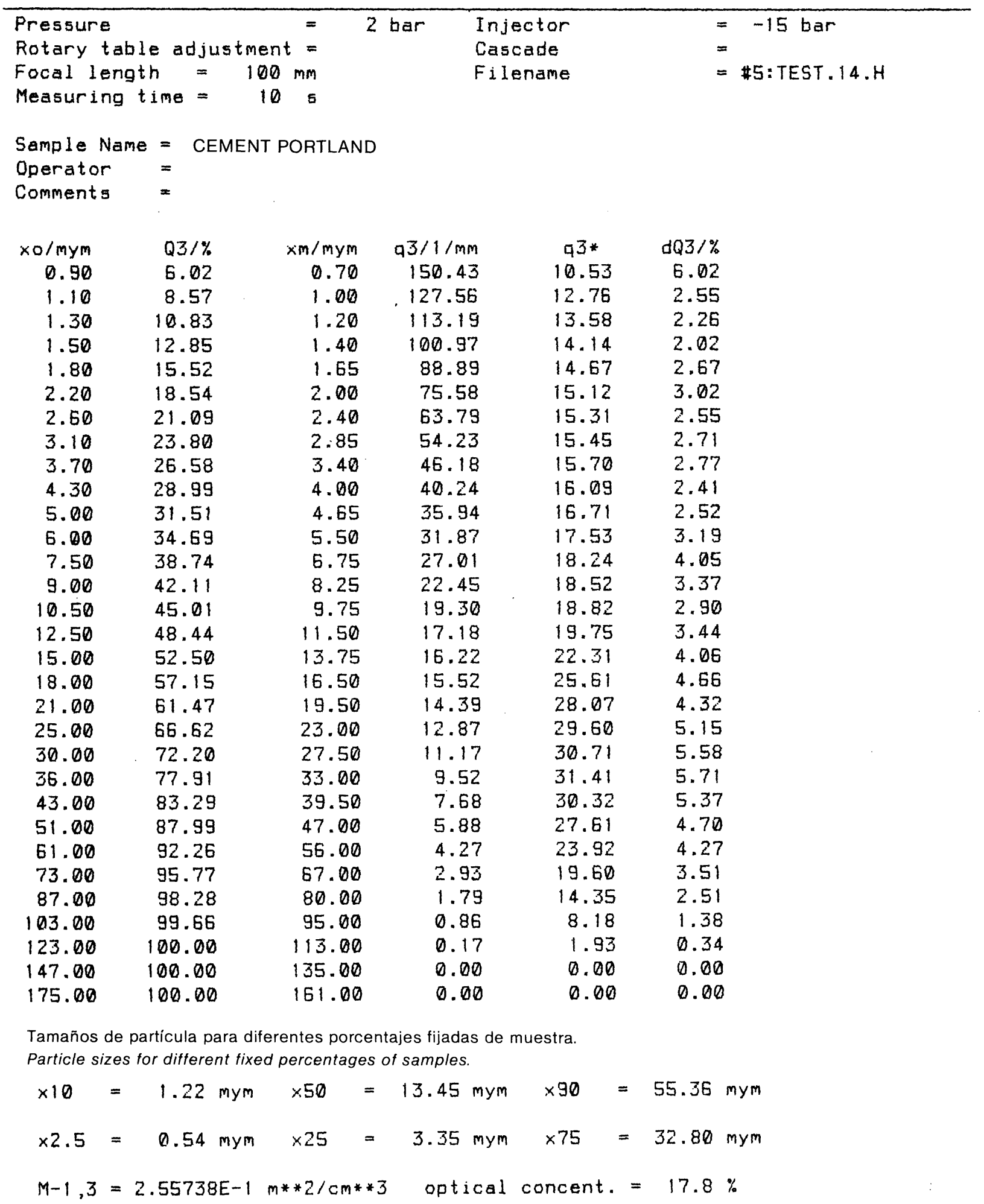




$\begin{array}{lll}\text { Dispersant }=\text { METHANOL } & \text { Sonication time } & =\text { G0s Pause= } \\ \text { Additive } & \text { Stirring rate } & = \\ \text { Focal length }=100 \mathrm{~mm} & \text { Filename } & \\ \text { Measuring time }=30 \mathrm{~s} & & \\ \text { Sample Name }=\text { CEMENT PORTLAND } & & \\ \text { Operator }= & & \end{array}$

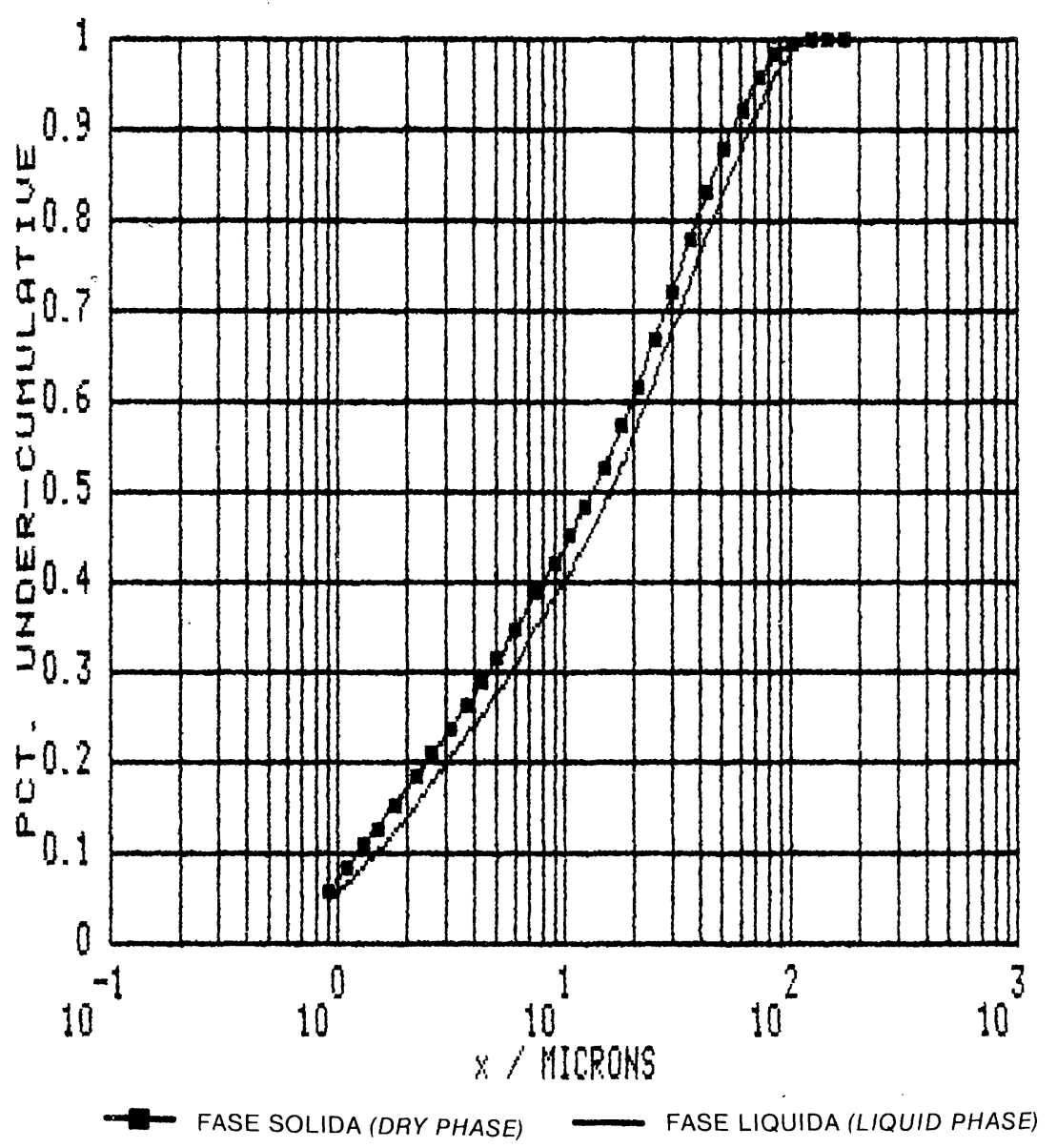

Fig. 7.- Comparación de las curvas de distribución del tamaño de partícula de un cemento portland, obtenidas en fase gaseosa y en fase líquida.

Fig. 7.-Comparison of distribution curves of particle size of a portland cement obtained in gas and liquid phases.

diferente de alimentación de la muestra no son notables, aunque, en cualquier caso, siempre se produce una pequeña diferencia entre suspensión en fase líquida y suspensión en fase gaseosa.

La figura 8 recoge los valores de densidad de distribución logarítmica frente al tamaño de partícula en $\mu \mathrm{m}$.

\section{B) Otros materiales}

En la figura 9 se encuentran las curvas de distribución de los tamaños de partícula de diferentes materiales empleados en el campo the sample are not noticeable, although, in any case, there is always a small difference between the method employing suspension in the liquid phase and suspension in the gas phase.

Figure 8 shows the values of the density of logaritmic distribution compared with particie size in $\mu \mathrm{m}$.

\section{B) Other materials}

Figure 9 shows the distribution curves of the particle sizes of the different materials employed in the field of the cement industry: 


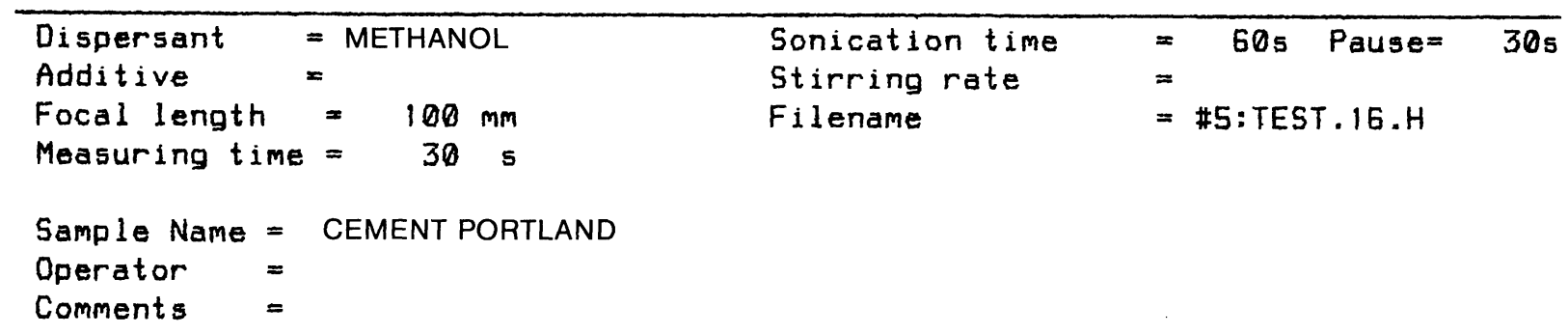

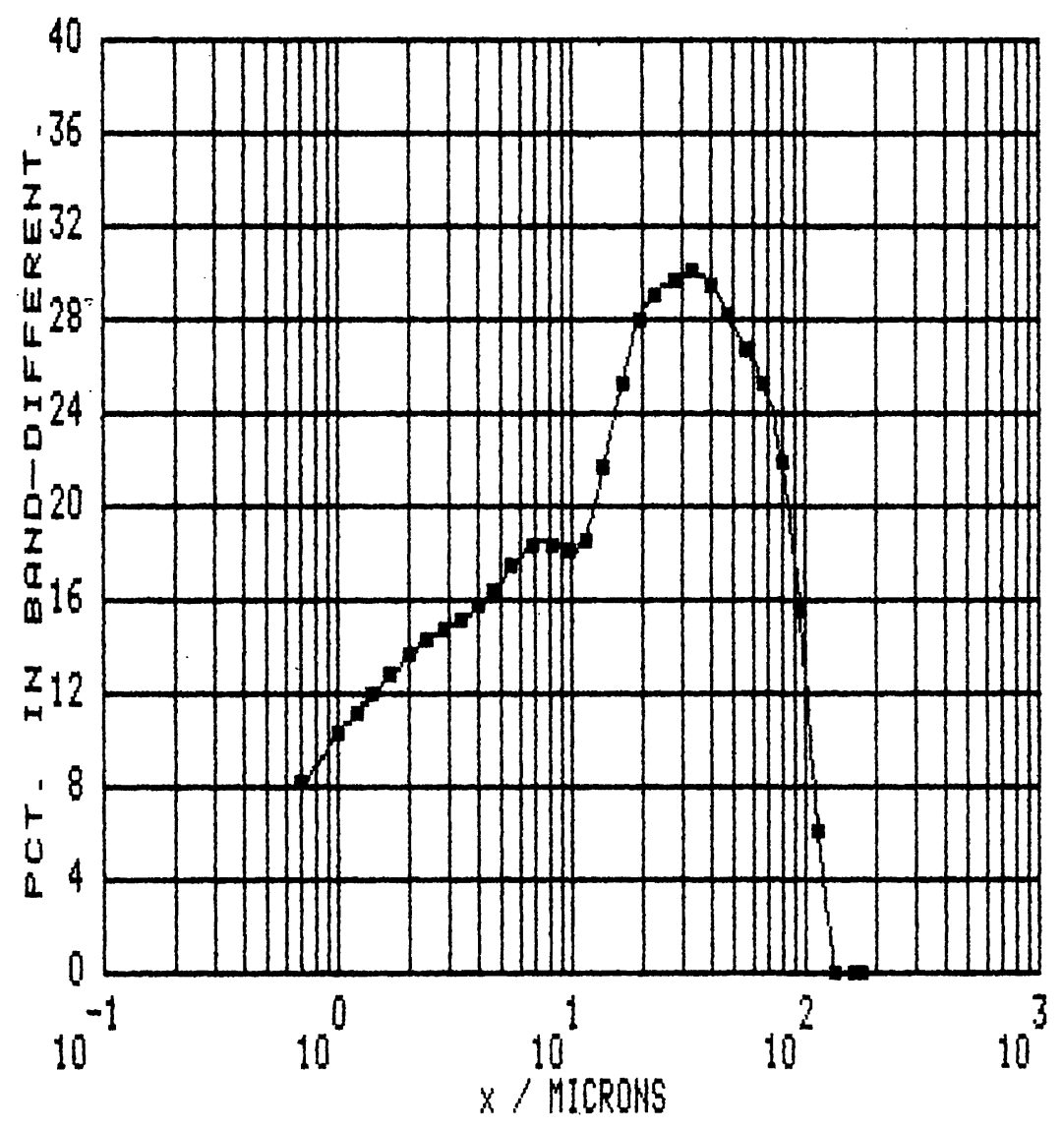

Fig. 8.-Curva de densidad de distribución.

Fig. 8.-Curve of distribution density.

del cemento: arcilla, yeso, caliza y roca opalina.

Se exponen de manera conjunta aun cuando las condiciones en que se han realizado los ensayos fueran distintas, tal como se detallan a continuación:

- Arcilla: suspensión en fase acuosa.

- Yeso: suspensión en fase gaseosa.

- Caliza: suspensión en fase líquida (alcohol isopropílico).

- Roca opalina: suspensión en fase líquida (alcohol isopropílico). clay, gypsum, limestone and opaline rock.

These figures together, even when the test conditions were different, as follows:

- Clay: suspension in the aqueous phase.

- Gypsum: suspension in the gas phase.

- Limestone: suspension in the liquid phase (isopropyl alcohol).

- Opaline rock: suspension in the liquid phase (isopropyl alcohol). 


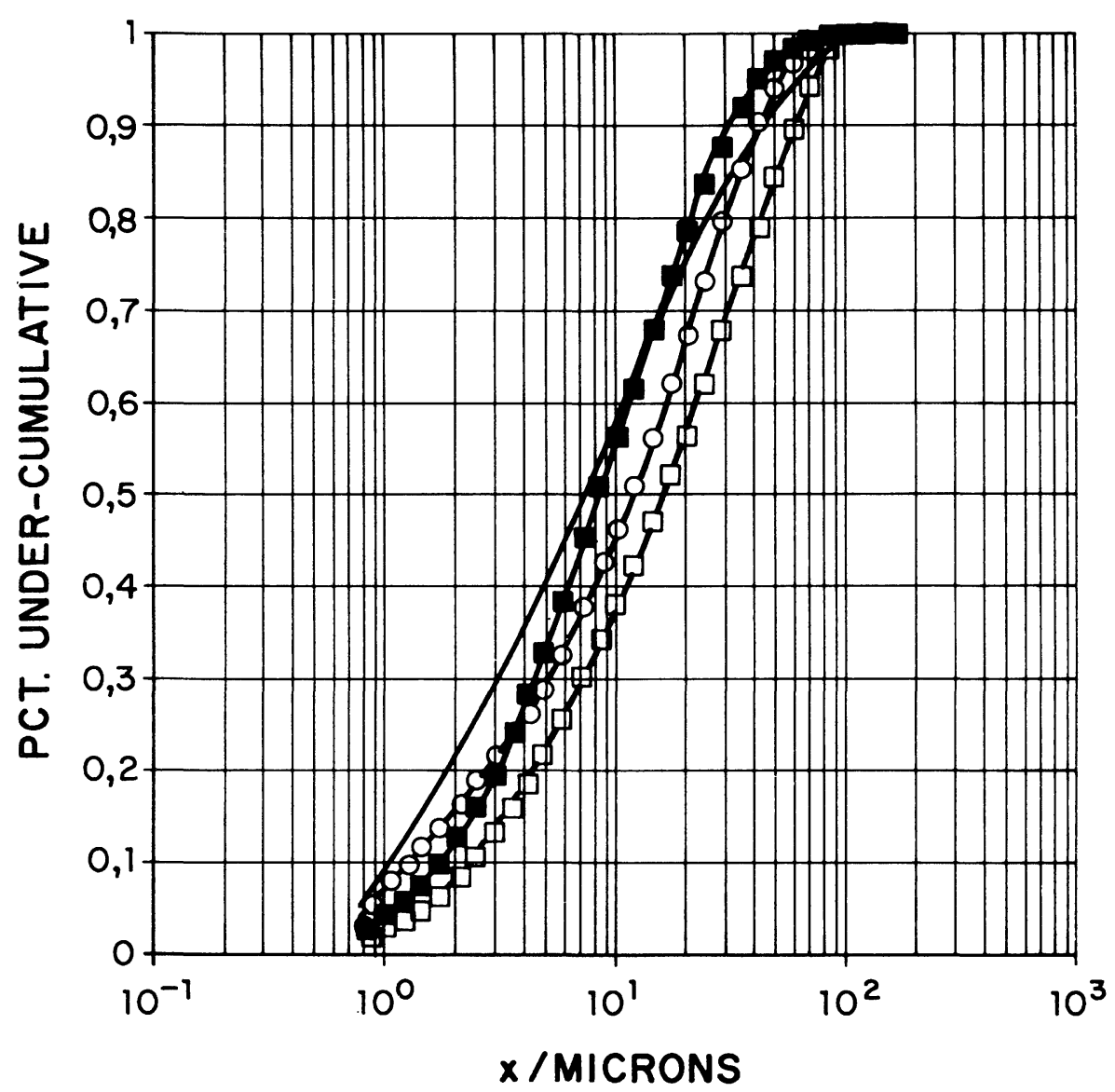

Fig. 9.-Curvas de distribución del tamaño de partícula de diversos materiales en el campo del cemento.

Fig. 9.-Distribution curve of particle size of different materials used in the cement industry.

\section{CONSIDERACIONES FINALES}

* Hoy por hoy, todavía no es posible conocer el tamaño de las particulas que componen un material. Cualquiera de los métodos desarrollados hasta ahora, parte de una serie de presupuestos hipotéticos (suposición de partículas esféricas, consiguiente adaptación e incorporación de factores de forma, ...), además de las dificultades propias inherentes a la técnica experimental concreta. Es por tanto, un campo abierto a la investigación.

* La espectrometría de difracción por rayos laser, y en concreto el equipo descrito, permite el análisis granulométrico de materiales tanto en vía húmeda como en seca, con la gran ventaja que supone el disponer de ambos sistemas de alimentación.

* Esta técnica también tiene su aplicación en el campo de los materiales de construcción

\section{FINAL REMARKS}

* Today, it is still not possible to discover two particle size of a given material. Any of the methods that have been developed until now start from a series of hypothetical assumptions (assumption of spherical particles, subsequent adaptation and incorporation of factors of shape... ), apart from the difficulties inherent to the experimental technique employed. The field is therefore open to further research.

* Diffraction spectrometry by laser beams, and in particular the equipment used in this paper, permits granulometric analysis of materials both while humid and when dry, with the considerable advantage of being able to use both power sources.

* The technique described in this paper has applications in the field of building 
(cemento, crudos, rocas siliceas, ...) y proporciona resultados en tiempo reducido.

* Con esta técnica se abren nuevas posibilidades de empleo. Por su rapidez, reproducibilidad de los resultados y el sofware disponible, se hace posible hacer el seguimiento de un proceso de fabricación industrial, mediante el control de las características de los productos (granulometría, pureza, ...).

* En el campo de la investigación el uso de la espectrometría de difracción por rayos laser proporciona nuevas líneas de estudio. Así por ejemplo se puede señalar como una vía de futuro la evolución de reacciones que puedan tener lugar entre una muestra sólida y la fase líquida reactiva en que se suspende inicialmente.

\section{AGRADECIMIENTO}

Los autores agradecen a la "Comisión Interministerial de Ciencias y Técnología" (DGCICYT) la ayuda financiera en este trabajo, y al Sr. Homedes por sus comentarios. materials (cement, raw, siliceous rocks...) and offers results in a reduced time.

* The technique described offers new work possibilities. Owing to its speed, the reproducibility of the results and the available software, it is possible to follow up a process of industrial manufacturing by monitoring the charecteristics of the product (granulometry, purity... ).

* In the field of research, the use of diffraction spectrometry by laser beams offers new lines of study. In this sense, for example, one could mention the future study of the development of reactions that might take place between a.solid sample and the reactive liquid phase in which the solid is initially suspended.

\section{ACKNOWLEDGEMENTS}

The authors should like to thank the "Comision Interministerial de Ciencia y Tecnologia" (DGCICYT) for financially supporting this work and to Sr. Homedes for his comments.

\section{BIBLIOGRAFIA}

(1) G. FRIGIONE, S. MARRA (1976): Cement and Concrete Research, 6, 113-128.

(2) R. L. BLAINE (1943): ASTM Bull, ASTBA, n. 125, 51-55.

(3) L. A. WAGNER (1933): Proc. ASTM, ASTA, n. 33, 553-570.

(4) H. M. ANDREASEN (1930): Zement, 19, n. 698, 725.

(5) L. CUSSINO, A. BRUGNOLI (1967): Industria Italiana del Cemento, 37, 831-848.

(6) H. LE DOUSSAL, D. MARTIN (1974): Revue des Matériaux de Construction, n. 690, 265-269.

(7) S. L. SARKAR (1985): Cement and Concrete Research, 15, 549-552.

(8) P. C. AITCIN, C. POULIN, S. L. SARKAR (1986): Cement and Concrete Research, 16, 671-678.

(9) G. BAUDET (1972): Bulletin de la Société Francaise de Céramique, n. 95, 31-51.

(10) J. KAZIMIRE (1981): Silikaty, n. 25, 339-345.

(11) G. PINTOR (1977): II Cemento, 75, n. 1, 15-21.

(12) J. FRAUNHOFER (1817): Gilberts Annalen der Physik, 56, 193-226.

(13) G. B. AIRY (1835): Trans. Camb. Phil. Soc., 5, 283-290.

(14) H. RUMPF, E. TURBA (1964): Ber. At. Keram, 41, 78-84.

(15) A. ZAHRADNICEK (1975): Staub-Reinhaltung Luft, 35, 226-231.

(16) M. R. PELTIER (1971): Revue de L'Industrie Minérale, 4, 319.

(17) M. R. PELTIER (1971): Ciments et Chaux, n. 602, 23.

(18) J. P. MERIC, J. F. CARON (1973): Revue des Matériaux de Construction, n. 676, 30-34.

(19) J. CORNILLAULT, P. EVRARD (1975): Cement Technology, 178-179.

(20) J. P. MERIC (1974): Revue des Matériaux de Construction, n. 678, 23.

(21) C. BARTHELEMY, J. C. HUGON (1976): Revue des Matériaux de Construction, n. 701, 227-229.

(22) L. MONTARO, A. BACHIORRINI (1985): II Cemento, 83, n. 3, 153-163. 